\title{
Language Use and Discoursal Strategies in Peer Religious Mentoring
}

\author{
Phyllis Ghim-Lian CHEW ${ }^{1}$ \\ National Institute of Education/Nanyang Technological University, \\ Singapore \\ e-mail:Phyllis.chew@nie.edu.sg
}

\begin{abstract}
This paper focuses on language use and discoursal strategies in an Islamic boys camp and draws from theoretical frameworks such as the ethnography of speaking, conversation analysis and discourse analysis as a means to examine the phenomena of religious mentoring and socialization. The article found that mentees were socialized through senior peers' linguistic strategies such as language choice and code-switching and discoursal strategies such as humor, mock-demonstrations - all of which played a major role in building solidarity, group support and brotherly bonding.

Keywords: language choice, discourse, mentoring, Islam, code-switching, storygenre
\end{abstract}

\footnotetext{
${ }^{1}$ Phyllis Ghim Lian CHEW is Associate Professor of Sociolinguisitcs/language Methodology at the Nanyang Technological Univeristy, Singapore.
} 


\section{INTRODUCTION}

There is as yet no universal agreement as to what precisely is meant by the term 'peer mentoring especially when it is by an elder peer to a junior peer in an educational-religious context. What is certain however is that research on mentoring in many domains such as education and workplaces shows that mentoring facilitates learning of the target materials and/or a collection of identities, affinities and values (Crasborn et al. 2011, Weinberg and Lankau 2010). The guidance and 'wisdom' from older and more experienced peers is believed to enhance the capacity of the younger and less experienced mentee. Even low levels of support from peer(s) have been linked to identify cognitive development and identity formation (Hawkey 1995, Zeichner 2010). Not surprisingly, most large businesses, universities, schools, hospitals, professional organizations, the military, and even small businesses have embraced mentoring as a practical, cost-effective, and inspiring way to prepare their members to mentor and be mentored.

Mentoring can be both informal and formal. Informal mentoring is a relationship that is created spontaneously without any assistance from the organization and is what used to happen in the past when mentoring relationship were long term, unstructured, casual and usually without specific goals (Sullivan, 2004). In contrast, formal mentoring refers to organizationally initiated efforts (Weinberg and Lankau, 2010) as in our case, where a madrasah (religious school) attempts to socialize pre-adolescents through their annual camp. While one-to-one mentorship is the most powerful combination to foster reflective action; in mass education, there are usually many mentees to one mentor. In such a situation mentoring becomes a relatively hierarchical and distant one resembling perhaps an informal classroom as evidenced by classroom discoursal patterns such as the typical IRF (initiation-response-feedback) structure. Whole class-mentoring, which is the focus of our paper, share similarities with the genre of motivational talks and public speaking.

In our madrasah, there is a ratio of 1 mentor to 10 mentees. The mentor, the older peers (between 21-35) are called upon to help socialize younger peers (aged 10-15) through talk and play. In talk, both will have one full day to construct knowledge and identity together. In play, both will have the opportunity to chat eyeball-to-eyeball, lock arms and engage in sports and games.

Mentoring in religio-educational settings has generally been underresearched and more so, where tweens are concerned. This study attempts to plug the gap through a study of language use and discoursal strategies in peer religious mentoring. Burgeoning research on the interface between language and religion not least because religion appears to have 're-emerged' as a potent force world-wide in the past two decade (cf. Klein 2015). Studies in religious contexts have used qualitative and quantitative apparatus such as interviews, questionnaire, participant observation, archival research; psychological experiment as well as fine-grained analysis of video (cf. Paveda and Polomares-Valera, 2005; Rosowsky 2006; Moore, 2008; Schmidt, 2011; Albakry and Ofori, 2011). In Singapore, studies have focused on religious education, the languages used to communicate with spirits, and how the language of the sacred texts influenced the way language is used in particular 
regions (cf. Spolsky 2003; Lai 2008; Tan 2010; Chew 2011). However, less has been done on the dimension of mentoring of the young despite childhood/adolescence being an extremely sensitive and vulnerable period of life. It is a time when areas in the brain that process emotion are beginning to change and when the young begin to question parental rules and values out of curiosity. So too, while Noor and Lai (2006), Muklis (2006), Sa'eda (2010), and Saeda and Chew (2014) have documented the many faces of madrasah education, theirs have not been a close-up of peer mentoring strategies in the formation of religious identities.

Children and youth classes have always been popular in Islam not least because the first word revealed by the Prophet Mohammed is the imperative 'iqra' (read):'Proclaim (or Read) In the name of your Lord and Cherisher, Who created...'(96:1). Hence, verses are read aloud to accompany birth and death and in times of distress or joy. The Quran, as Islam's sacred book, is used extensively in the liturgy in the mosques and in private devotions. Peer mentoring in formal and informal classrooms with a view to understanding the Quran has thus always been popular in Islam and the cultivation of camaraderie among adherents a common

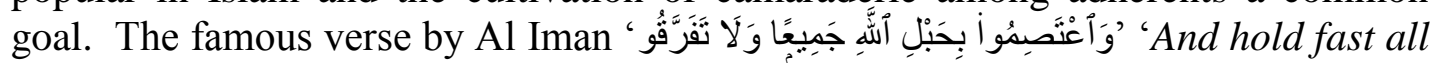
together to the rope of Allah and never be divided' (Al Imran, 3:103) is of memorable note here as it calls for a brotherhood and a unity of thought and action among Muslims. In Islam, religious mentors, such as those found in our study, may be placed half way between teachers in the madrasahs and the ulamas (scholars) in the mosque simply because they often dispense with the formality of the teacher in the classroom or of the scholar-clergy speaking from the pulpit.

\section{THE RESEARCH SITE}

The Muslims comprises $15 \%$ of the population of Singapore, a thriving multilingual and multicultural nation state in Southeast Asia. $90 \%$ of them belong to the Shafii School of Law of the Sunni Islam. They subscribe to the five pillars namely, salat or prayer, the payment of zakat a tax, puasa or fasting, profession of faith or syahadat ('There is no God but Allah and Mohammad is his prophet') and the haj (pilgrimage to Mecca). They are predominantly Malay in race and hence, a study of Muslim youth is also a study of the Malay community in Singapore. Like other religious groups in Singapore, Singapore Muslims are peaceful inhabits and this paper is a study of moderate Islam, of 'everyday' routine religio-educational activities.

A word must be said about the Singapore language situation since the dominant focus of the paper is linguistic. There are four official languages: Mandarin, Tamil, Malay and English, and almost all Singaporeans are bilingual. However, being bilingual does not mean any of the two languages but rather English and one other official language. English is the medium of instruction in Singapore schools, being the language for all major school examinations. Therefore, it is not surprising to find that religious mentoring may take place not so much in the child's mother tongue (Malay), as one would expect and which was traditionally the case, but increasingly in the medium of standard English or the local patois, Singlish. In multicultural and multilingual contexts, which are the norm in most parts of the 
world today, different languages may be drawn upon to aid in the communication and mentoring process, and this is no different in Singapore (Rugby 2007). In addition, both mentors and mentees in my research are multilinguals and have access to discoursal tools such as code-switching and code-mixing which are creative and practical ways to assist in communication and identify formation (cf. Woolard, 2004; Khaerunnisa, 2016)

The mentees come from one of the many weekend madrashs in Singapore, and the madrasah in question, ' $Z$ ', tutors over a thousand students aged 6 to 16 in the weekend and is a non-profit enterprise. The camp is an annual affair for boys aged 11-12 and one which promises to be something different for several reasons (see Table 1). First, it is only for boys and for once, their regular female classmates, are excluded. Second, the venue is set in a small idyllic rural mosque, away from the hustle and bustle of city life, unlike their classroom which is in the heart of their busy city neighborhood. Instead of 'seatwork' -- normal chairs and tables fronting a teacher --- the lessons are conducted on the 'casual' open-air verandah of a small rural (village) mosque, affording a more relaxed atmosphere, since they are all seated on the floor and not according to any prescribed seating arrangement. Third, boys of the same age from other classes of the madrasah will also be attending and here then is an opportunity to make new friends of the same age. It is a 'whole day' and not half a day, the latter being their normal weekend madrasah schedule. Their 'teachers' for the day are their older male peers, not their usual adult female teachers. Hitherto, the boys have only been exposed to female teachers as madrasahs often face a problem hiring male teachers, the latter attracted by more lucrative job opportunities elsewhere. Hence, their religious education had been attended to by a more 'motherly' or 'sisterly' kind of discourse, in contrast to 'brothers' who can also offer each other jocular humour and other kind of male repartee without selfconscious attention from the opposite sex.

In Table 1, there is a lot more play and group work and games and quizzes in the annual camp, such as beach games, which are absent in their normal weekend class. Shared activities may include the playing of musical instruments, beach games and in this programme, football or working together in groups to solve a problem. Content is not organized through traditional subject headings in Arabic, such as, fiqh, Akhlag, sirah or tarikh but through the more personable virtues named in English such as 'truthfulness', 'steadfastnesss', 'honesty' and 'helpfulness'. Communal meals, activities, games are interspersed between the teachings of the virtues.

Table 1: A Comparison of the Camp Programme and a Typical Weekend School Programme

\begin{tabular}{|l|l|}
\hline Camp Programme & Normal Weekend School Programme \\
\hline & \\
Setting: boys camp rural mosque & Setting: classroom in city \\
Instructors: alumni, older youths & Instructors: professional women teachers \\
Participants: boys only & Participants: boys and girls of same age \\
Frequency: annually & Frequency: weekly \\
Programme: & Programme: \\
\hline
\end{tabular}

JELTL, Vol. 1 (3), 2016 
09.00 Prayers

09.30 Talk Truthfulness \& Steadfastness

10.30 Morning tea

11.00 Beach games

12.00 Noon prayers and lunch

12.20 Quiz

14.00 Talk on honesty and helpfulness

15.00 Group work

$15.30 \mathrm{Tea}$

16.00 Football \& beach games

18.00 Closing prayer
09.00 Memorization \& recitation Verses 09.30 Aqidah and fiqh -faith and practice 10.30 Akhlaq - character and life skills 11.30 Sirah and tarikh - social and civilization Islam

12.00 Iqra/Quran Reading - Quranic literacy.

01.00 Closing prayer

There are nine male mentors with an average age of 25 managing the programme and they take turns in presenting the talks. Their presentation styles are basically similar. All of them are Malay - and Muslim and they are paid an honorarium for the planning and management of the camp. Most of them are ex-pupils of the school, graduated and holding different job scopes in Singapore. They have volunteered to be at the camp to help mentor the younger ones, just as they themselves were mentored when they were tweens a decade before. Their goals in this weekend camp are to enable tweens to embrace Islam more closely and to identify themselves more confidently as Muslims. Throughout the camp, mentors refer to themselves as 'abang' (older brother) and occasionally address the boys as 'adik' (younger brother) although there is no blood-relationship. Male bonding is a term that is used in the social sciences to describe patterns of friendship and/or cooperation in men (Spear 2005). The expression is sometimes used synonymously with the word 'camaraderie' or 'homophily', a desire to develop relationships with others similar to oneself (French 2011). A kind of homo-sociality is therefore advocated, that is, a same-sex relationship that are not of a romantic or sexual nature, with their female teachers discreetly in the background, ready to assert routine discipline should it be necessary. This is not unnecessarily uncommon in Islam or Middle Eastern culture where differing gender roles predominant.

\section{RESEARCH METHOD}

To study language use and discoursal strategies of peer-group mentoring, I videoed the entire camp proceedings. In a first-pass view of the video-recordings, I made rough transcriptions of the data, highlighting segments that needed further clarification or which were particularly interesting. I then began to focus on salient patterns of interaction and language practices. Grounding my analytic observations on the videos, field notes, and transcripts at several stages of refinement, I coded the data according to content (such as Quranic literacy, Islamic history, Arabic handwriting practice), pedagogical practice (such as recitations, group work, games, quizzes, audio-visual, etc.). After completing the coding stage, I proceeded to transcribe in detail representative examples of classroom interactions. During the course of the recordings, I adopted the role of observer and minimized my 
participation in the camp. I did not intervene in any way between teachers and students although on occasions, the mentors would remind the mentees of my presence, and the presence of the camera, especially as a form of 'teasing'. I identified nineteen episodes grouped under 'virtues' such as faithfulness, truthfulness, loyalty diligence, perseverance, kindness, hospitality, graciousness, courage and assertiveness as particularly interesting. Due to the length constraints of this paper, it is not practical to analyze all of them; hence, I have selected only one theme, truthfulness, which may be said to represent the rest of the data in terms of discoursal strategies and language use. Truthfulness may be said to be the most representational since according to the organizer of the camp, 'it is the foundation of all virtues' and subsumes other qualities such as honesty and integrity. In the study, longer speeches of discourse, divided into different sections, have been chosen for display, so as to enable us to see how the theme of truthfulness interacts with linguistic and discoursal strategies. Malay is presented in italics and its English translations are placed within brackets.

\section{FINDINGS}

The episodes chosen for analysis in this paper are taken from the discourse of the chief mentor (lines 41-591), the oldest youth among the group, as his discoursal mentorinig style is the most representative. He is standing and speaking to the mentees, all ninety of them, seated on the floor. On the other hand, the boy's regular female teachers who have accompanied them to the camp, are all seated at the back of the hall, discreetly invisible. Some are arranging the food while others are keeping a loose supervisory eye on the proceedings. The boys have just recited their morning prayer and are now gathered together cross-legged on the floor to listen to the talk. The other mentors are also listening to him and they will "follow" his style when they themselves take the center-stage in the camp.

From the onset, one notes that peer religious mentoring is dependent on two main strategies - one which is language-based, that is, code-switching and codemixing; while the other is discoursal, that is, the use of the story genre. One notices that although the medium of instruction is in English, or rather Singlish, intersentential code-switching at the clause or sentence boundary occurs throughout the discourse.

\subsection{Code Switching and Code-mixing of English, Singlish and Malay}

Beginning his talk, the mentor identifies the camp site with his childhood, and in so doing, becomes part of the 'tradition' historically and in the present. This intersentential alternation of codes sets the discoursal tone for the camp.

(1) You all will remember this place. Ah dulu, datang ke sini ... belajar ... (inaudible).(Ah, I used to come here ... to study ...)

Although the mentees understand English, it being the language of the head, that is, the language whereby a livelihood is made; Malay may be said to be the language of the heart - it being the language of the mosque and the spirit. It should be noted that it is not so much English but Singlish, which is an English-based creole or patois 
spoken colloquially in Singapore across the races and which invokes a Singaporean identity. It has a unique syntax as may be seen in for example, (1) 'You all will remember this place' (Standard English equivalent: You should all remember this place) and (2) 'What is truthful? '(Standard English equivalent: What is truthfulness?)

The sentences of the mentors alternate between English and Malay, seen once again in the following:

(2) What is truthful? Siapa kat sini tak pernah cakap bohong? (Is there anyone here who has not told a lie before?) Everyone here has lied. Siapakah kat sini cakap bohong (Is there anyone here who tells lies) Almost every day?

By beginning his talk in Singlish/English in (1), the mentor indirectly acknowledges Singlish as the working language of Singapore and the medium of instruction in all schools. However, by switching almost immediately into Malay, he is identifying himself in the tradition of the ustaz (religious teacher), who has traditionally used Malay for religious instruction, thereby ensuring the continuation of an authoritative tradition. However, the mentor distances himself as an 'authority' since he wishes to be seen more as a mentor than as an ustaz. To do this, other discoursal strategies to generate mentorship and 'collegiality' are invoked. Here, the dominant strategy is that of code-switching, from Singlish to Malay, the latter code adding an additional layer of kampong (community/tribal) spirit. This is seen in (2) in the predominance of the shortened form of 'kat' for 'dekat' and 'cakap' in several instances for 'bercakap'. Usually the prefix 'ber-', just like other similar prefixes as 'me-', 'ter-' and ' $d i$-', is usually attached to verbs to form a well constructed sentence in terms of grammar in Malay. A sentence without such prefixes in Malay is automatically deemed informal and colloquial such as in the last two mentoring sentences listed in (2): Siapa kat sini tak pernah (ber)cakap bohong? and Siapakah kat sini (ber)cakap bohong. The switch to colloquial Malay is obviously to evoke camaraderie as Malay is also the 'familiar' mother tongue of most of the mentees. A combination of both standard English and standard Malay ensures authority while a combination of Singlish and colloquial Malay ensures trust and homophily.

Another mainstay of the mentor's discoursal strategy is the use of the rhetorical question whenever a new topic is introduced. In (2), the assertion, 'Everyone has lied' separates two rhetorical questions. With regards to the second rhetorical question, it is repeated twice in Malay for emphasis: 'Is there anyone here who has not told a lie before? However, it elicits no response as it is obvious to all that it is a rhetorical question meant as either an introduction to the topic or a focusing device. Nevertheless, this attention getting statement is able to generate a sense of comfortable discomfort. This discomfort then allows the mentor in the next utterance to 'soften' his stand as abang (elder), reduce the social distance, and give the mentoring or counseling needed, through the use of the modifier 'sometimes':

(3) We all sometimes do tell lies but we must try ... we must try our best ... jangan suka cakap bohong (don't make it into a habit telling lies). 
In (3), the use of the personal pronoun 'I' and the inclusive 'we', which imitates direct informal speaking, enables the mentor to teasingly 'admonish' the boys for not telling the truth since collectively though their silence, they had not admitted to ever lying in the group session. This solicited smiles and laughter from the boys, since they realized that 'we all boys are guilty'. Such humor or teasing enables mentors to speak off record, to make light of an otherwise serious matter and to express opinions without a restrictive accountability to themselves or others (Pichler 2006). In (4), the mentor then continues with a gentle admonition in Malay and Singlish:

(4). That's why, just now, when I asked you siapa sini tak pernah cakap bohong, tak da orang angkat tangan. Betul. Maknanya, semua tak cakap bohong ... Apa? Semua tak cakap bohong yang mereka tak pernah bohong. Pikir ya, pikir. (Who had not told lies before, no one put up hands? That's good!. This shows that none of you tell lies ... ! How can? (laughter) No one here lies??. Think about that!)

However, when the accusation is put in the positive - that is, he asks not who has 'told lies' (a finger-pointing which was meant to be outrageous and attentiongenerating) but rather who would like to be 'trustworthy', almost every boy has their hands up:

(5) Siapa suka cakap ... ini memang mulutnya ... jangan angkat tangan (Who likes to tell on ... this is his choice ... don't put up your hands). Ah, ok lah Those yang angkat tangan tu (who put up hands) .... If you say you are trustworthy, you are taking the first step ... yes .... I want to be a trustworthy person.

Reframing in the positive is therefore an important strategy used in mentoring to elicit receptiveness and rapport.

As this mentoring takes place in the sacred precinct of the mosque, reference must inevitably be made to Faith since the site is on he hallowed ground of the mosque. Hence, we find the mentor routinely referencing the Koran, and in (6), repetition is used for emphasis:

(6). Whatever there is in the Koran, you learn it .... There is an ayat (verse) ... there is an ayat (verse). Look at your slide ... be truthful .... (quoted from the holy scripture - inaudible ): ... What is this ... This is the place of all salvation and fulfillment of all desires? What is this place? Janna, janna, dalam syurga (Heaven, heaven, in heaven).

Prophet Mohammad Sallallah ho Alaihe wa aali hi Wasallam (S.A.W.) (Peace and Blessings upon him and His Family) who said 'truthfulness leads to righteousness and righteousness leads to ..... (Inaudible)... and the man who insists on telling the truth will become a truthful person. Falsehood leads to wickedness.'

The use of the Arabic ayat to signal 'verse' and janna to signal 'heaven' enable a grounding of the religious register. Religious contexts usually demand highly 
marked and self-conscious use of linguistic resources and in such contexts; language must occasionally allude to the presence of the deity. The mention of S.A.W.(Sallallahu 'Alaihe wa Sallam) 'May the peace and blessings of Allah be upon him.' ) each time the prophet's name is mentioned is another example and such invocation transports the audience to a more exalted realm - the realm of the sacred in the larger Islamic diaspora of Muslim brotherhood. Such sacred phrases suspends or alter certain aspects of everyday ways of speaking and reminds the mentees of the larger Islamic brotherhood. Besides the use of S.A.W., other sacred formulaic are conspicuous, reminding participants of the elevated context as well as their own unique identities as Muslims (cf. Hashim and Hassan 2011):

(7). Bismillahhirrahmannirrahim, (Peace be upon you, usually at closing of a section)

Alhamdulillah (Praise to God)

Inshallah (God willing usually as an appendage to any statement regarding the future)

Salaam alaykum (a greeting used among a participants)

In (7), religious formulaic phrases may be regarded as a form of 'contextualization cue' (Gumperz 1982) since it signals contextual presuppositions. Formulas such as as-Salamu 'alaykum' (Peace be upon you), 'al-hamdu lillah' (thanks be to God) 'subhan Allah' ( glory to God) and 'astagh-firullah' (may God forgive us) also contain within them whole paradigms of Islamic identities.

However, Arabic is used only as a 'sprinkle' as the mentor is conscious to place himself not so much as a religious teacher or expert but more as an older sibling. Besides, Arabic is the third language for the students and one which is difficult for many of the boys since it is not a language in general use in Singapore. Hence, the use of Arabic religious terms is accompanied by concrete explanations in either English or Malay. In (8) for example, the Arabic 'janna' is explained through idealistic metaphors of 'garden', 'river' and 'reward' as well as through practical everyday lexis such as 'clean' and 'cockroaches':

(8). your janna (heaven), your heaven. And your janna (heaven) will be full of garden and full of river flowing underneath the garden. This is just part of the reward. This is the reward for being truthful: the garden of janna (heaven), the garden you tak payah bersihkan (do not need to clean up), it is always clean. Tak da lipas, tak da lalang.... Semua tak da (there is no cockroach, no weed ... there is nothing).

Reward and punishment is a theme that operates throughout the talk. In Islam, they are the two pillars which will uphold moral character, and which must necessarily be instilled into young minds:

(9). Right now, you cannot see your reward but later when you go to heaven, you will... ok? So, if you are being truthful, you try to be truthful and you want to be a truthful person, , you say the truth, always say the truth. And what will be your reward? The thing is ... kita tak nampak sekarang (we don't see it now) because the reward will be in the hereafter, Inshallah, ... 
di akhirat ... baru tak mahu cakap bohong... (in the hereafter ... then only we want to stop telling lies) by then it is already too late. Ok?

While reward is stressed in the above, punishment is stressed in the following through the concrete image of mock 'caning', demonstrated visually though the physical realia of a cane:

(10).When you cakap bohong dengan your parents (lie to your parents) then very serious! (line 111). If a Muslim ... kalau suka bohong (if he likes to lie) seven years old or nine years old, you must start to use cane. Kalau tak nak solat ... pah (demonstrates the act of gentle caning), bukan uui (demonstrates the act of severe caning) ... tapi sebat ... (if don't want to pray ...) like that, pah (demonstration of a mock caning to the sound of boisterous laughter). Ah, itu kecik-kecik kan, nanti dah besar, dia tak nak cakap bohong) (Ah, that is when he is small, when he grows up, he will not lie).

The demonstration of a mock physical canning elicits laughter from the mentees, since this is not something that is demonstrated when there are females in the class. But the point of the canning is not lost, as seen in the last line which acts as a refrain. Respect for parents as referred to in (10) is another prominent thread in the discourse since it is only with parental consent that the boys have been sent to the camp. The internalization of family values is important, one of the objectives of the camp being to ensure that Muslim 'youths' may continue with strong familial values.

\subsection{The Use of the Story in Religious Mentoring}

Stories are a mainstay in mentoring (Le Page and Tabouret-Keller 1985) and in our data, stories may be taken from a religious or non-religious source or are personal in origin. In the following, the mentor uses a universal tale from Aesop, 'The boy who cries wolf' and links it to the lesson on truthfulness. As usual, stories are told through English, Malay and Arabic.

(10). And I tell you what will happen to you if you always tell lies. Right, you know the story of the boy who cried wolf ... he cried 'wolf, wolf, wolf'. Everyone datang (come) to save the sheep from the wolf. Then, nampak tak $d a$ wolf (didn't see any wolf). Aiyah, disappointed!. So he cry 'wolf wolf wolf' again. Semua datang lagi (Everyone rushed to him again). The third day ... he try it again - but nobody came ---and this time there were real wolves - so the sheep all gone. So, you must try to be truthful, ok.

Sekali cakap bohong, tak pa... orang boleh terima. Dua kali cakap bohong... eh ini tak kenalah ni. (If you tell lie once, it is all right .... People can accept it. If you do it the second time ... something must be wrong). The third time, ok pasallah (no one will take you seriously)... no one will trust you. You know if you are in court, you have to tell the truth, nothing but the truth. If you still lie, nobody will trust you anymore. 
The story is quickly narrated through connectives such as 'then', the third day' 'again' and the moral is given at the end in both Singlish and Malay. One notes too that non-standard Malay expressions are signaled by the use of contractions: Sekali (ber)cakap bohong, tak pa... orang boleh terima. Dua kali (ber)cakap bohong... eh ini tak kenalah ni. Once again the dropping of 'ber' in 'cakap', 'ti' in 'tak'. 'I' in 'ini' and 'a' in 'apa'. There is also a lack of grammatical markers such as 'di' before 'terima' and the abundant use of colloquial particles such as 'eh' and 'ni'. The last line of episode (10) is particularly interesting because when the mentor speaks about truthfulness and its implication in the courts of justice and everyday life, it is narrated in standard English as if to confer the secular governmental authority of Singapore.

Another type of story is through the use of 'secrets' as a means of building suspense and to facilitate the creation of intimacy through a private sharing:

(11). Can I see here if I tell you a secret, you can keep it to yourself and you won't tell anyone else? Can I have a show of hands? (All the boys put their hands up). And I tell you, it actually happened to one of my friends. $\mathrm{He}$ likes to tell lies ... when I was younger lah ....no one wants to be friend with him. He becomes very unpopular ... dia suka cakap bohong (He likes to tell lies).

Rhetorical questions such as 'you won't tell anyone else?' and 'Can I have a show of hands?' helps achieve a 'dramatic effect' (Sichyova, 2005). Although it is a secret, it is introduced as a 'tease' which enables the mentor to discuss publicly normally 'taboo' subjects. Joke making is also a way of coping with suffering and shared jokes pull a group together and is a stress reliever. (David et al. 2006). The 'secret' turns out to be an incident with a friend, 'when I was younger lah' - indicating a story from his childhood; with the 'lah' particle of Singlish to indicate the private domain. What happened was that in one of the long sessions in the mosque, his friend had been either too excited or had forgotten to go to the toilet or was indisposed, hence resulting in the 'yellowish water' in the mosque, causing all around him to quickly finish their praying and 'disappear'. This is told as an example of an embarrassing experience but it is crowned with a moral that if we do something 'wrong' inadvertently, we should always be responsible and 'clean up the mess'. It elicits empathy 'how would you feel if you are in his place.'

(13). If people ask you, if people tell you something, lebih-lebih lagi (more importantly) if ... (inaudible) ... itu apa ... perkara yang memalukan orang tu .... Dulu saya kecik-kecik .... tengah solat ... pelajar akhir ... terkejut .... Ada air... Siapa kat sini P5? Ada P5 ke? (what is that ... something that embarrassed people ... when I was small ... while praying ... the last student .... got startled ... There was water ... who is in P5 here? Anyone here in P5?) Older ya. That time, I was in P5 ... ada air yang kuning. Habis solat ... lepas sudah lari (there was yellowish water. After praying, everyone disappeared) ... that time I was with him ... lepas bersihkan ... Alhamdulillah (after cleaning up ... Praise to God), I did not do that dan sampai sekarang ... hanya dua orang tahu. Sekarang kita dah besar... 
(until today, only two persons know about this. Now, we have grown up) so we looked back and we laughed at this story.

But how would you feel if you are in his place dan semua orang memalukannya di depan orang? Suka ke? Tak sukakan? Dan nampaknya dia (pointing to a student) pun tahu, tak suka. Tak da orang suka. Tak suka. Itu memalukan kita saja ... (and everyone embarrassed him in front of everyone? Do you like that? No, right? And it seems that he also knows, don't like). So keep this secret okay?

(14) is a well-known story is one from the Hadith, of an old women who in her ignorance, used to throw stones at the prophet. Stories follow the usual convention of orientation-complication-resolution and are narrated in informal language with ubiquitous code switching, rhetorical devices, turn of voice and physical action.

(14). ORIENTATION: When he was walking ... he wanted to go to the mosque to pray subuh (morning prayer)... there was this one lady... an old lady. She would always throw shit, throw stones, throw trash to the prophet ... he would always do that ... sorry, she would always do that.

COMPLICATION: And the prophet s.a.w. would just keep quiet ... he did not do that (showed action of throwing). Sabar(Be patient)! And then one day, one day, when the prophet wanted to go to bersolat subuh (perform the morning prayer), then she wasn't there... manalah tahu (who knew where she was)? The prophet went to the mosque and the lady wasn't there. He got to know the lady was sick.

RESOLUTION The prophet went for solat subuh. He came back with two of his sahabat (friend). What did he do? There were all the stones, take them... (showed action of throwing). Did he do that? What did he do? He visited ... ya melawat (visited) (repeating answer from one of the students)... dia melawat nenek tua tadi tu. Nenek tua yang buat macam tadi .... Nenek berbepluk masuk Islam di situ juga (... he visited the old lady, the old lady who did all these things .... The old lady immediately converted to Islam) and I don't know what happened to the nenek because I wasn't there (laughter) .

EPILOGUE OK, this is a good example of being nice to everyone ... of being nice so important lah ... for teaching ...Islam tu, tak boleh paksa. Kalau dia nak masuk Islam (There is no force in Islam. If people want to become Muslim), we open our arms. Tak boleh (Cannot) force. You cannot force. Orang tak nak masuk Islam (if people don't want to become Muslim).... we cannot force him.

In (14), Singlish and colloquial Malay, as elsewhere are used to give the discourse a non-conflictual and non-adversarial tone. 
the frequent use of particles, for example: pah, $e h, u h, n i, y a$.

The use of abbreviations for example: tak da (tidak ada) (4),(8),(10),(13); tak (tidak) (2), (4),(8), (9), (10), (11), (13), (14); kat sini dah (dekat sini sudah) (2);Orang masuk Islam (14); dulu (dahulu), (1), (13);tak nak (tidak hendak) (10), (14).

Not unlike English, the Malay language also generally observes the rule of $\mathrm{SV}(\mathrm{O})$ in the construction of a sentence, the violation of which renders the sentence informal and conversational, even if the subject is recoverable from the context:

(1): Ah dulu, datang ke sini ... (last time $\varnothing$ come here)

(9): ... di akhirat ... baru tak mahu cakap bohong... (Finally, Ø don't want to lie)

(14): Tak boleh ( Ø you cannot)

In the domain of lexis, an interesting contrast is seen in the use of 'high' religious Arabic terms from the religious register, such as S.A.W. and lexical items from a Malay childhood such as:

Kecik (kecil) ( 10) (13)

Pikir (fikir) (4)

macam (seperti) (14)

\section{CONCLUSION}

Peer religious mentoring is a tried and tested means of enabling tweens to associate more intimately with the values of their faith. It is an effort particularly pertinent in view of media reports of increased violent juvenile crime, teen pregnancy, and suicide. While not all of these social concerns are moral in nature, and most have complex origins, there is a growing trend towards linking the solutions and related social problems to the teaching of moral and social values in both religious and secular schools. The parents, teachers and mentors of our mentees from the weekend madrasahs, are acutely cognizant of this.

There is a dearth of research as to how peer support works in the religious domain. This silence is surprising in view of the fact that mentoring of all kinds has increasingly been shown to have significant educational, psychological and socioreligious impact. Notwithstanding, the disciplines of language, education and religion may be said to be inter-connected and their interfaces are in need of further research; and this study is a preliminary effort in this direction.

This paper is a snapshot of linguistic- discoursal strategies in peer religious mentoring which is basic in the building of identity and solidarity in a religious community. Discoursal strategies include the judicious use of various types of stories, occasional reference to the sacred text(s) and humor. The procession of rhetorical questions, first and second person pronouns, repetition, questions and answers, etc. also contribute in their own ways to the generation of warmth, inclusion and rapport between mentors and mentees.

More significantly, this study has shown that mentors are able to use differing languages (English, Malay, Arabic) to subtly index larger scale ideologies or primordial belongings of Malayness and Islamia and in so doing allow the 
transcendence of more superficial teacher-student boundaries to one of deep member-shipping and insidership. Here, English represents the more progressive world, 'the other', and the globalized and legalistic world at large. Singlish represents the Singapore community. Malay as mother-tongue connotes not just racial affiliation but also communal solidarity with blood ties. Arabic symbolizes the Middle East and the language of the Quran and since the venue is a mosque, a sprinkling of Arabic terms reminds all mentees where the 'center' is or should be. Code-switching is then combined with style-shifting to cement everything together.

In brief, this study has shown the linguistic and discoursal strategies of peer religious mentoring as a central ingredient in the socialization of tweens and as a subtle means of identity formation. Compared to the average mainstream secular classroom, we found no significant differences in linguistic and discoursal strategies in the religious camp. This is probably due to the fact that this is a typical, traditional everyday Muslim group situated in a very orderly city state. As with all other kinds of mentoring, peer religious mentoring in everyday Islam is essentially moderate and the annual camp for boys is basically about fostering self-confidence, faith and identity. Like the professional clergy, the peer religious mentor has historically and continue to be an important but little-known part of the institutional apparatus to help mentees develop, imbibe, and identify with the 'proper' values.

\section{REFERENCES}

Albakry, Mohammed A. and Ofori, Dominic M. (2011). Ghanaian English and code-switching in Catholic churches, World Englishes, 30, (4), 515-532.

Chew,Phyllis Ghim Lian. (2011). Metaphors of Change: Adolescent Singaporeans Switching Religion. In Omoniyi, T (Ed.), The Sociology of Language and Religion. Change, Conflict and Accommodation (pp. 156-190). London: Palgrave Macmillan.

Crasborn, F, Hennissen, P. Brouwer, N. Korthagen, F. and Bergen T. ( 2011). Exploring a two-dimensional model of mentor teacher roles in mentoring dialogues. Teaching and Teacher Education, 27, (2), 320-331.

David, Maya Khemlani, Jan,Jariah Mohd., Kow, Karen Yip Cheng, and Yoong, David Soon Chye ( 2006). Function and role of laughter in Malaysian women's and men's talk. Multilingua (26), 77-99.

Gumperz, J. J. (1982). Discourse strategies. Cambridge: Cambridge University Press.

French, D. C., Purwono, U., Triwahyuni A. ( 2011). Friendship and the religiosity of Indonesian Muslim adolescents. Journal of Youth and Adolescence. Advanced Online publication: Doi: 10.1007/s10964-011-9645-7.

Hawkey, K. (1995). Learning from peers: the experience of student teachers in school-based teacher Education, Journal of Teacher Education, 46, (3), 175183.

Khaerunnisa, Lisa. (2016). An EFL Teacher's Code Switching in a Young Learners' Class. Indonesian Journal of EFL and Linguistics, Vol. 1 (1), 2016 
Klein, Wendy (2015). Responding to Bullying: Language Socialization and Religious Identification in Classes for Sikh Youth. Journal of Language, Identity and Education, 14, 19-35.

Lai, Ah Eng (2008) (ed.) Religious Diversity y in Singapore. Singapore: Institute of Policy Studies.

Le Page, R. B. and Tabouret-Keller A (1985). Acts of identity. Creole-based approaches to identity and ethnicity. Cambridge: Cambridge university press.

Moore, Leslie C. (2008). Body, text and talk in Maroua Fulbe Quaranic schooling. Text and talk 28, ( 5), 643-665.

Muklis, Abu Bakar (2006). Between state interests and citizen rights: whither the madrasah? In Noor Aishah Abdul Rahman and Lai, Ah Eng, (Eds.) Secularism and Spirituality. Seeing integrated knowledge and success in madrasah education in Singapore (pp.29-57).. Singapore: Institute of policy Studies.

Noor Aishah Abdul Rahman and Lai, Ah Eng (2006). (Eds.). Secularism and Spirituality. Seeing integrated knowledge and success in madrasah education in Singapore. Singapore: Institute of policy studies.29-57.

Pichler Pia (2006). Multifunctional teasing as a resource for identity construction in the talkof British Bangladeshi girls. Journal of Sociolinguistics, 10,(2), 225-249

Poveda, David, and Palomares-Valera, Manuel (2005). Religious Genres, Entextualization and Literacy in Gitano, Language in Society, Vol. 34, No. 1 (Feb., 2005), pp. 87-115.

Prinstein M J. and Dodge, K. A. (eds.). (2008) .Understanding peer influence in children and adolescents. New York: Guilford.

Rosowsky, Andrey (2006). The role of liturgical literacy in UK Muslim communities. In Omoniyi, Tope and Fishman, Joshua A. (eds.), Explorations in the Sociology of Language and Religion. (pp.309-325) Amsterdam: John Benjamins Publishing Company.

Rubdy, Rani (2007). Singlish in the School: An impediment or resource. Journal of Multilingual and Multicultural Development, 28, (4), 208-323.

Saeda, Buang (2010). Muslim education and globalization: the re-(de)positioning of languages and curriculum content in Southeast Asia. In Vaish, Viniti (Ed.) Globalization of language and culture in Asia. The impact of globalization processes on language. (pp.34-60). London: Continuum.

Saeda, Buang and Chew, Phyllis Ghim Lian (2014). Muslim Education in the 2lst Century: Asian Perspectives. New York: Routledge.

Schmidt, Garbi (2011). Understanding and Approaching Muslim Visibilities: Lessons Learned from a Fieldwork-based Study of Muslims in Copenhagen, Ethnic and Racial Studies 34, (7), 1216-1229.

Sichyova, Olgan (2005). A note on Russian-English code switching, World Englishes, 24, (4), pp. 487-494.

Speer, Susan A. (2005). 'Gender and language: 'sex difference' perspectives'. In Speer, Susan A. Gender talk: feminism, discourse and conversation analysis.( pp. 20-45). London New York: Routledge.

Spolsky, Bernard (2003). Religion as a site of Language Contact. Annual Review of Applied Linguistics 23, 81-94. 
Sullivan, C. G. (2004). How to mentor in the midst of change. Virginia: Association of supervision and curriculum development.

Tan, Kenneth Paul (2010). Pragmatic secularism, Civil Religion and Political Legitimacy in Singapore. In Heng, Siam-Heng Michael and Ten, Chin Liew (Eds.) State and Secularism. Perspectives form Asia. (pp. 339-358). Singapore: World Scientific,

Weinburg, F. J. and Lankau, M. J. (2010). Formal mentoring programs: a mentor centric and longitudinal analyzes. Journal of Management, 28, (1), 31.

Zeichner, K. (2010). Rethinking the connections between campus courses and field experiences in college-and university-based teacher education, Journal of Teacher education, 61, (1), 89-99.

\section{Phyllis Ghim-Lian CHEW}

English Language and Literature

National Institute of Education/Nanyang Technological University

1 Nanyang Drive

Singapore 637616

Republic of Singapore

Email: Phyllis.chew@nie.edu.sg

Tel: +6567903395 